\title{
ARID Domain
}

National Cancer Institute

\section{Source}

National Cancer Institute. ARID Domain. NCI Thesaurus. Code C14094.

The approximately 100-amino acid ARID (AT -Rich Interaction Domain) DNA-binding domain occurs in some transcriptional regulators (and perhaps modifiers of chromatin structure) involved in embryonic development, cell lineage, and cell cycle control. The domain shows more diversity in structure and function than the highly conserved sequence suggests: at least six alpha helices separated by beta-strands, loops, or turns. Although Bright, dead ringer, and MRF-2 preferentially bind to AT-rich sites, DNA binding of ARID-proteins is not necessarily sequence specific; ARID protein p270 of the SWI-SNF complex exhibits non-specific DNA binding activity. ARID family proteins may be involved in a wide range of DNA interactions. Inappropriate expression of ARID proteins is increasingly implicated in tumorigenesis. 